\title{
Histological and Ultrastructural Studies on the Effect of Amoxicillin on the Liver of Mice Foetuses
}

\author{
Original \\ Article \\ Sahar A. Sabry, Heba I. Rashad, Mohamed A. Shahin \\ Department of Biological and Geological Sciences, Faculty of Education, Ain Shams \\ University, Egypt
}

\begin{abstract}
Introduction: In spite of the beneficial role of the beta-lactam antibiotics in the treatment of many cases of urinary tract infections, acute otitis media, and pneumonia, yet some medical reports incriminating it in producing certain adverse consequences following its use. Antibiotics remain important in pregnancy and may be second to only iron and food supplement.

Aim of Work: Hence, the present investigation was carried out to evaluate the effect of two doses of the beta-lactam antibiotic amoxicillin on the liver of maternally treated foetuses.

Materials and Methods: The pregnant female mice were allocated into three groups. The pregnant mothers of the first group served as control group (injected intra peritoneally with the drug solvent) and those of the other two groups were injected intra peritoneally for 8 days from day 7 till day 14 during gestation with the low dose ( $205 \mathrm{mg} / \mathrm{kg}$ body weight) and high dose ( 820 $\mathrm{mg} / \mathrm{kg}$ body weight) of the beta-lactam antibiotics amoxicillin.

Results: The histological examination of the foetal liver sections of amoxicillin-treated groups showed vacuolar and fatty degenerations in the cytoplasm of the hepatocytes, as well as inflammatory cell infiltration. At the ultrastructure level, the hepatocytes of maternally treated foetuses revealed conspicuous alternations, represented by devastations of mitochondria that displayed loss of their cristae and their internal matrices materials. Fragmentation of the cisternae of rough endoplasmic reticulum into smaller stacks was also observed.

Conclusion: The use of such doses of the beta-lactam antibiotic amoxicillin induces morphological alterations in fotal liver of mice subjected to this antibiotic during the period of gestation.
\end{abstract}

Received: 27 August 2019, Accepted: 20 November 2019

Key Words: Amoxicillin, histopathology, liver, ultrastrucure.

Corresponding Author: Sahar A. Sabry, PhD, Department of Biological and Geological Sciences, Faculty of Education, Ain Shams University, Egypt, Tel.: +20 1204427241, E-mail: saharsabry84@yahoo.com

ISSN: 1110-0559, Vol. 43, No. 1

\section{INTRODUCTION}

Antibiotics occupied the second place among drugs used during gestation; the first and foremost commonly prescribed medications during pregnancy are vitamins ${ }^{[1]}$. Accordingly, antibiotics are widely prescribed during pregnancy as the most important modality for treating and preventing infections. In spite of the potential risks of teratogenicity for some antibiotics, their prescription in certain infections is a must, and may serve as effective and life-saving ${ }^{[2]}$. Although the role of antibiotics in medical applications in humans and animals is well documented, the high incidences of their misuse, and/or the potential development of resistant bacteria were reported ${ }^{[3 \text { and } 4]}$.

Beta-lactam antibiotics represent a large group of pharmaceuticals that are widely used in human and veterinary medicine ${ }^{[5]}$. However, in spite of the benefits of these antibiotics, they are incriminated in producing certain teratogenic and toxic side effects in mammals. Worthwhile, most of the available literature dealing with such adverse effects of these drugs are mainly concentrated on the biochemical and physiological aspects. It is quite evident that the effects of these drugs on pregnant females and their foetuses have received diminutive attention. Amoxicillin is among these drugs which is widely handled in the Egyptian market. Therefore, a need had sprung to evaluate the possible hepato-toxic effects which may be induced by treatment with this beta-lactam antibiotic.

\section{MATERIAL AND METHODS}

Dosages and route of administration of the drug

The chosen doses of the drug for mice were calculated on the basis of body surface area according to the conversion table $\mathrm{e}^{[6 \text { and } 7]}$. Accordingly, two doses of amoxicillin were used in the present investigation; 205 and $820 \mathrm{mg} / \mathrm{kg}$ body weight and were considered as the low and high doses, respectively. The chosen dosages were nearly comparable to the human effective low and high therapeutic doses ${ }^{[8]}$. It is worthy of mention that, the selection of dosages and duration are correspondent with amoxicillin doses used in previous investigations performed in mice and rats ${ }^{[9-15]}$. In the present investigation, the used dosages of amoxicillin were given through the intraperitoneal route since the 
administration of amoxicillin to mice and rats through the oral route is characterized by its low bioavailability ${ }^{[16 \text { and } 17]}$. The authors attributed this reduction in the bioavailability of amoxicillin to the presystemic degradation of amoxicillin in the alimentary canal of these rodents due to the lack of hepatic first-pass metabolism.

\section{Experimental animals}

The present investigation is carried out on mature albino mice of pure CD-1 strain with an average body weight of 20-30g obtained from the breeding unit of Theodor Bilharz Research Institute (TBRI), Imbaba, Giza, A.R.Egypt. The experiments were performed parallel to the ethical standards and according to the international guides for the Care and Use of Laboratory Animal. Pregnancy was achieved by housing one adult virgin female with one wellmarked fertile male overnight, from 5 pm until 9 am of the next day. Successful mating was indicated either by the presence of the vaginal plug or by the presence of sperms in the vaginal smears ${ }^{[18]}$. Females which give positive vaginal smears are considered pregnant and the day of detection was defined as the first day of gestation.

\section{Experimental design}

The present investigation was carried out on a group of 24 adult female pregnant mice which were being divided into three study groups ( 8 mice each). The mice were placed in separate cages labeled according to the group they belonged to. The mothers of the first group were considered as the control group (C) and injected intraperitoneally with $0.1 \mathrm{ml}$ physiological saline solution (the solvent of the drug) daily for 8 days during gestation from day 7 till day 14 of pregnancy.The animals of the other two groups (A and B) are the drug-treated groups and treatment of these groups occurred by intraperitoneal injection with amoxicillin ( 205 and $820 \mathrm{mg} / \mathrm{kg}$ body weight, respectively) for 8 days during pregnancy from day 7 till day 14 of gestation. Pregnant mice of both control and experimental groups were sacrificed on day 19 of pregnancy. They were dissected and their uteri were removed, placed in normal saline solution and the foetuses were taken out.

\section{Histological preparations}

For the histological and histopathological studies of the target organ, small pieces of the liver of the control and maternally treated foetuses were removed, fixed in $10 \%$ formalin and aqueous Bouin fixatives. The fixation was achieved for 24 hours. Then the specimens were dehydrated in an ascending series of ethyl alcohol, cleared in terpineol for 2-3 days and washed in benzene. The specimens were placed in 3 changes of melting paraffin wax for infiltration and embedded to form paraffin blocks. Serial transverse sections $5 \mu \mathrm{m}$ thick were cut from selected blocks and mounted on clean glass slides. Paraffin sections were stained with hematoxylin and eosin, dehydrated, cleared in xylol and mounted by DPX. Stained sections of the liver of control and maternally treated foetuses were examined carefully with light microscope and photomicrographs were made as requested.

\section{Electron microscopic preparations}

For ultrastructural evaluation by transmission electron microscope, the freshly excised liver tissues of the control and the maternally treated foetuses were cut into small pieces and fixed directly in cold 4 FIG (i.e. $4 \%$ formalin $+1 \%$ glutaraldehyde adjusted at $\mathrm{pH} 2.2$ ) for 24 hours. Tissue samples were then post-fixed in $1 \%$ osmium tetroxide in $0.1 \mathrm{M}$ phosphate buffer ( $\mathrm{pH} 7.3$ ), dehydrated in graded ethanolic series, culminating in $100 \%$ acetone, and infiltrated with epoxide resin. After polymerization overnight at $60^{\circ} \mathrm{C}$, semi-thin sections $(0.5 \mu \mathrm{m})$ were cut, stained with $1 \%$ toluidine blue in sodium borate and examined with a light microscope. Areas of hepatic tissues were selected and blocks were trimmed accordingly. Ultrathin sections were cut, mounted on 200 mesh copper grids, and stained with uranyl acetate and lead citrate $^{[19}$ and 20$]$. The stained grids were examined and photographed by a JEOL-JEM-1400EX-transmission electron microscope, at the Regional Center for Mycology and Biotechnology (RCMB) Al-Azhar University.

\section{RESULTS}

\section{Histological and Histopathological Observations}

\section{The liver}

\section{A-Histology of the liver of the control mice foetuses}

The liver of 19-days old control mice foetuses is composed of numerous hepatic lobules which are indistinctly demarcated since the interlobular connective tissue is poorly developed. The portal tracts displaced between the hepatic lobules are less markedly distinguished. Each lobule possesses a central vein and contains numerous strands of hepatocytes. The central vein is outlined by a thin endothelium, consisting of simple squamous epithelial cells containing flattened nuclei and is surrounded by a thin connective tissue layer (Figure 1). The hepatic strands anastomose to form a network enclosing a system of tortuous blood sinusoids as revealed in (Figures1 and 2).

The hepatic cells are large in size, polygonal in shape and possess ill-defined cell boundaries and coarsely granular cytoplasm. Their nuclei are large and vesicular; each has one or more prominent nucleoli as seen in (Figure 2). The blood sinusoids are lined by thin endothelial cells interspersed by large Kupffer cells. The sinusoidal endothelium is formed of flattened cells with flattened nuclei. Large phagocytic Kupffer cells being oval-shaped or elongated cells found in the luminal part of the hepatic sinusoids; each possesses a large oval nucleus (Figure 1).

\section{B-Histopathological observations}

\section{I-foetal liver of maternally treated mice with the low dose of amoxicillin}

The liver of 19-days old foetuses maternally treated with $205 \mathrm{mg} / \mathrm{kg}$ body weight of amoxicillin from day 7 to 
day 14 of gestation showed features of alterations in the hepatic tissues. The cytoplasm of the hepatocytes exhibited vacuolar degenerations; their nuclei exhibited obvious symptoms of pyknosis, karyorrhexis, and karyolysis. Pyknotic nuclei appear shrunk and condensed as single, round globules of uniformly intense, basophilic masses. Karyorrhexised nuclei showed the disintegration of the chromatin into several deeply stained fragments. However, karyolysed nuclei appeared as empty disintegrated vesicles was shown in (Figures 3 and 4). Collection of inflammatory cells was observed dispersed in the hepatic tissue as illustrated in figures 3 and4. In addition, the endothelial lining cells of the central veins were conspicuously eroded as seen in (Figure 4).

\section{II- Foetal liver of maternally treated mice with the high dose of amoxicillin}

The liver of 19-days old fetuses maternally treated with $820 \mathrm{mg} / \mathrm{kg}$ body weight of amoxicillin from day 7 to day 14 of gestation revealed severe pathological lesions of the hepatic cell strands and their vasculatures. The cytoplasm of the hepatocytes showed clear features of fatty degeneration and their nuclei manifested signs of deterioration including pyknosis,and even stages of karyolysis (Figures 5 and 6). The hepatic central veins exhibited erosion of their lining epithelia (Figure 5) and inflammatory cellular infiltration between the hepatic cells was noticed in (Figure 6).

\section{C- Ultrastructural examination of the liver of the control mice foetuses}

Electron microscopical observations of the liver cells of the control mice foetuses illustrated hepatocytes with a polygonal outline and central large nuclei.The cytoplasm of hepatocytes have numerous spherical or ovoid mitochondria; their structural details are obviously distinct with outer and inner membranes, internal ridges or cristae and mitochondrial matrices (Figures 7-9). Distinct rough endoplasmic reticulum in the form of elongated and parallel cisternae, being attached with the outer nuclear membrane and dispersed into the cytoplasm with their obvious ribosomes were seen .Numerous free ribosomes and dense aggregates of glycogen rosettes were also observed (Figures 8 and 9). The spherical nucleus appears with thedistinct nuclear envelope and the nucleoplasm showed aggregations of loose euchromatin and compact heterochromatin materials (Figures 8 and 9).

Higher magnification view illustrating a bile canaliculus bordered by hepatocytes is shown in (Figure 10). Adjacent hepatocytes are separated by narrow intercellular spaces with occasional occluding junctional complexes (zonulaoccludens). The zonulaoccludens was observed at the convergence of the hepatic plasma membranes bordering the bile canaliculus (Figure 10).

(Figures 11 and 12) illustratea hepatic sinusoid localized between the hepatocytes. The endothelial wall of the hepatic sinusoidpossesses a phagocyticKupffer cell at the boundary of the sinusoidal lumen. The same figures alsoshow part of the space ofDisse near the border of the hepatocytes and around the lumen of the hepatic sinusoid.

\section{D-Ultrastructural examination of the foetal liver of} maternally treated mice

\section{I- Foetal liver of maternally treated mice with the low dose of amoxicillin}

In the liver of 19-days old foetuses maternally treated with $205 \mathrm{mg} / \mathrm{kg}$ body weight of amoxicillin from day 7 to day 14 of pregnancy the electron microscopic examination of the hepatocytes revealed marked signs of damage. The mitochondria exhibited swelling with obvious condensation of their indistinguishable matrices that displayed high electron density as shown in (Figures 13 and 14). The rough endoplasmic reticulum showed fragmentation of their cisternae into smaller stacks accompanied with loss of their attached ribosomes. The nuclei of the hepatocytes showed irregular nuclear envelope as illustrated in (Figure 13). Myelin figures enclosing dense bodies were also observed.The hepatic sinusoids exhibited a hypertrophied Kupffer cells with an irregular surface may be accompanied with an extension of filopodia. The cytoplasm contained lysosomes, a few individual profiles of rough endoplasmic reticulum and a large lobulated nucleus with marginated large masses of heterochromatin and irregular nuclear envelope as demonstrated in (Figure 14).

\section{II- Foetal liver of maternally treated mice with the high dose of amoxicillin}

The hepatocytes of foetuses maternally treated with $820 \mathrm{mg} / \mathrm{kg}$ body weight of amoxicillin from day 7 to day 14 of pregnancy showed obvious changes in their ultrastructural configuration. The mitochondria were severely damaged; some of them lost parts of their internal ridges and matrices, other mitochondria displayed a complete loss of their matrices. The rough endoplasmic reticulum showed the devastation of their cisternae; they were partially fragmented into smaller stacks and exhibited marked degranulation (Figures 15-17). The nuclei became shrunken and manifested aggregation of heterochromatin on the inner membrane of the irregular nuclear envelope as seen in (Figure 16). The defensive Kupffer cells showed degenerated cytoplasm and pyknotic nuclei within irregular nuclear envelopes as illustrated in (Figure 18). 


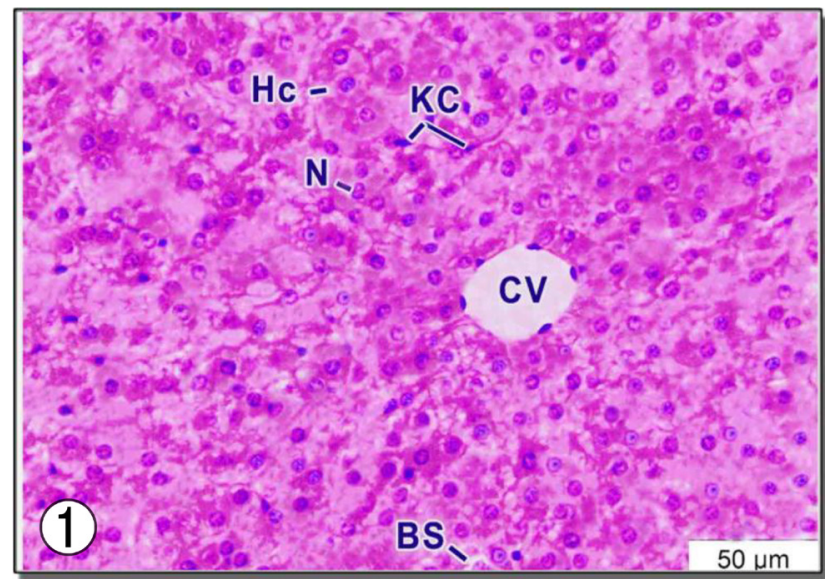

Fig. 1: Showing strands of hepatocytes $(\mathrm{Hc})$ with their nuclei (N). Thecentral vein $(\mathrm{CV})$ is outlined by a thin endothelium consisting of simple squamous epithelial cells containing flattened nuclei. Besides,blood sinusoid(BS)and Kupffer cells(KC) are also observed.

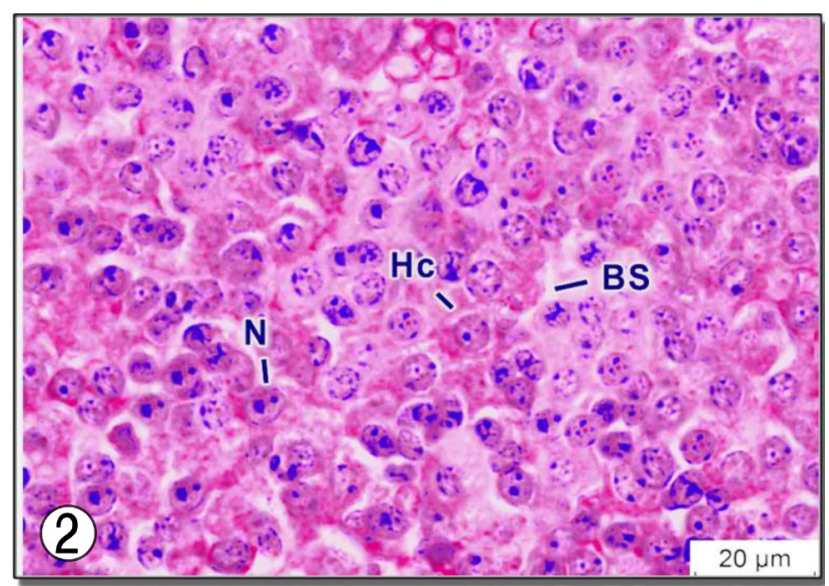

Fig. 2: Illustrating the hepatocytes $(\mathrm{Hc})$ with their large vesicular nuclei $(\mathrm{N})$; each has one or more prominent nucleoli. The blood sinusoids (BS) are also noted.

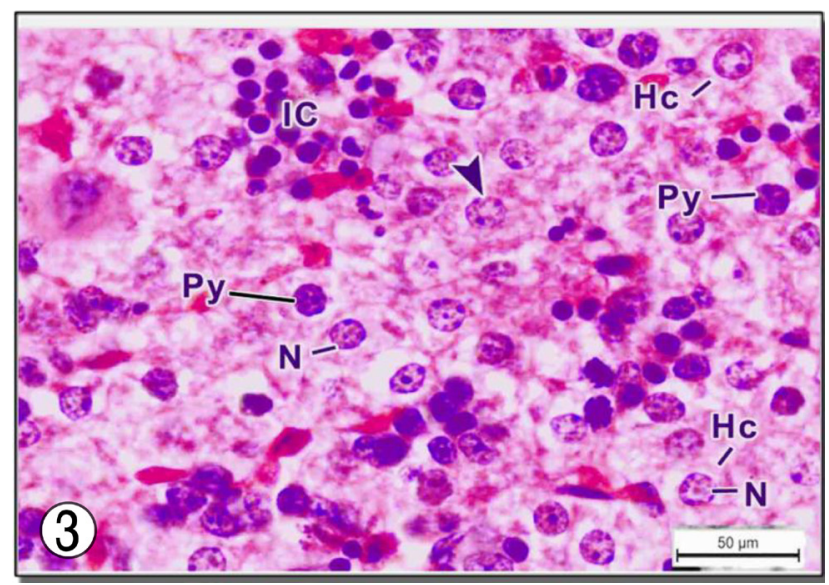

Fig. 3: Showing hepatocytes $(\mathrm{Hc})$ exhibit vacuolar degeneration. The nuclei(N) of these cells show symptoms of pyknosis(Py)and karyolysis (arrowhead). Focal collection of inflammatory cells (IC) is marked near the devastated hepatic tissue.

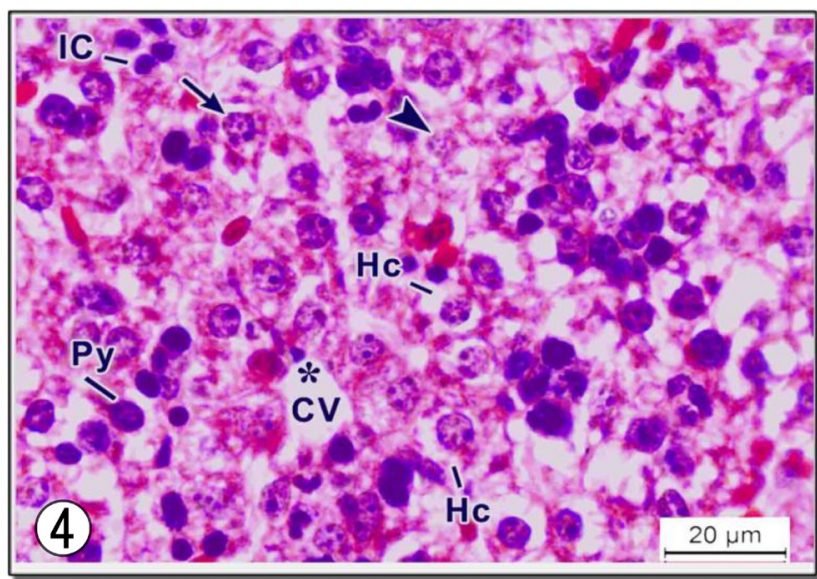

Fig. 4: Displaying erosion of the lining endothelial lining cells $(*)$ of the central vein $(\mathrm{CV})$. Note that the deteriorated hepatocytes (Hc) manifest vacuolardegeneration, and their nucleishow clear features ofpyknosis(Py),karyorrhexis (arrow) and karyolysis(arrowhead). Focal infiltration with inflammatory cells (IC) is also designated.

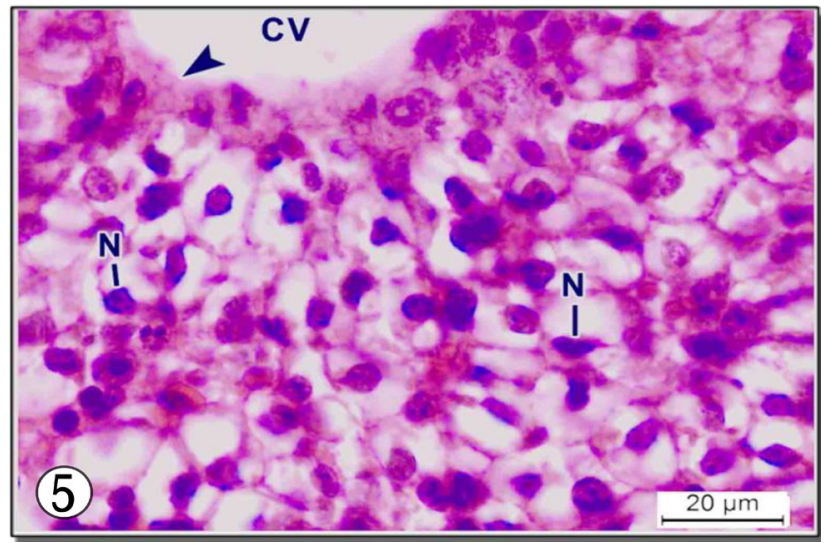

Fig. 5: Demonstrating fatty degenerationof the cytoplasm of the hepatocytes. Their nuclei(N) show features of pyknosis. Erosion of the endothelial lining cells (arrowhead) of the central vein(CV) is also noticed.

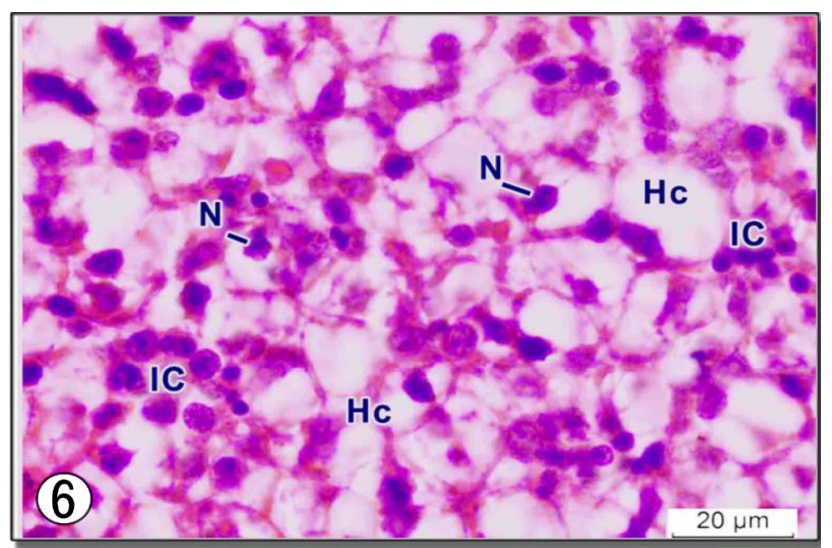

Fig. 6: Displaying the infiltration of the hepatic tissue with inflammatory cells (IC). The highly affected hepatocytes (Hc) manifest fatty degeneration in their cytoplasm; their nuclei $(\mathrm{N})$ display features of pyknosis. 


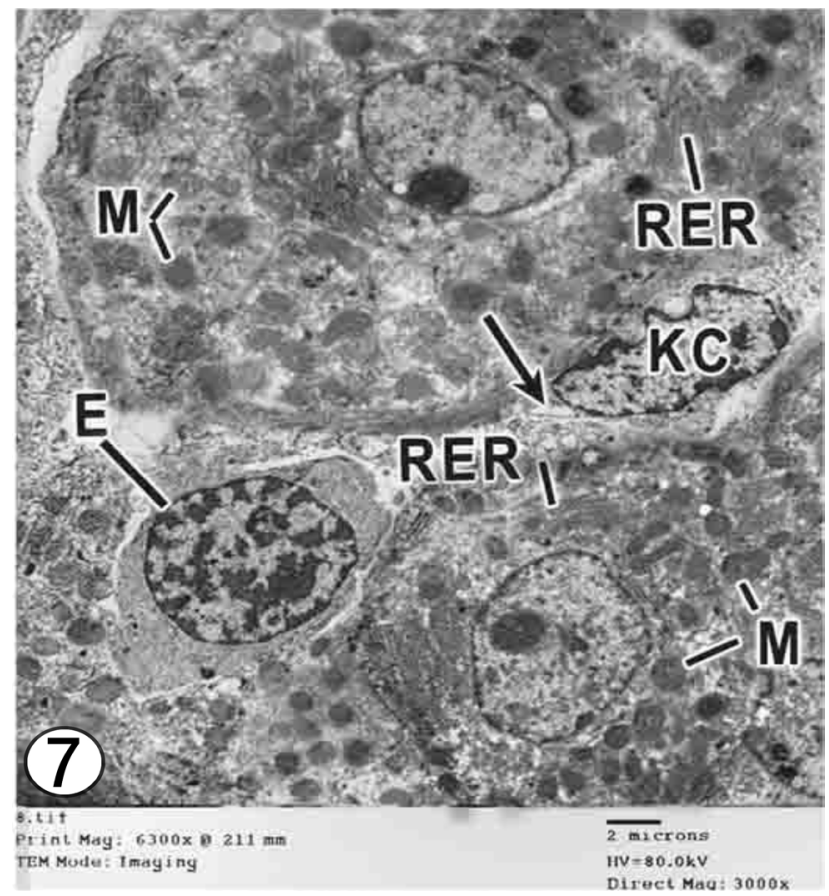

Fig. 7: Presents a low magnification electron micrograph of the hepatocytes showing spherical nuclei along with cytoplasmic organelles including various shapes of mitochondria $(\mathrm{M})$, and cisternae of rough endoplasmic reticulum (RER). Hepatic sinusoid separated from adjacent hepatocytes by the space of Disse,Kupffer cell (KC) localized in the sinusoidal lumen (arrow), and an erythroblast (E) are also seen.

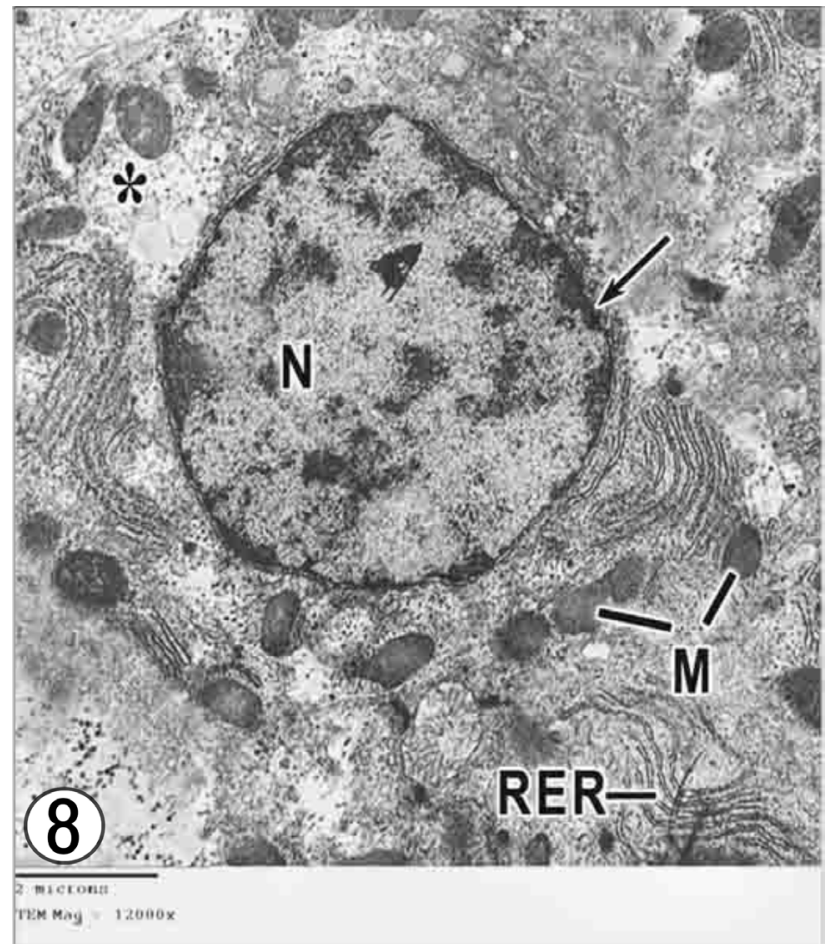

Fig. 8: Showing a relatively high magnification of a hepatocyte. A large round nucleus $(\mathrm{N})$ of the hepatocyte with its nuclear envelope (arrow) and nucleoplasm with euchromatin and heterochromatin are seen. Many profiles of rough endoplasmic reticulum (RER) can be observed throughout the cytoplasm, often intermixed with mitochondria (M). Glycogen granules $(*)$ appear distributed throughout the cytoplasm.

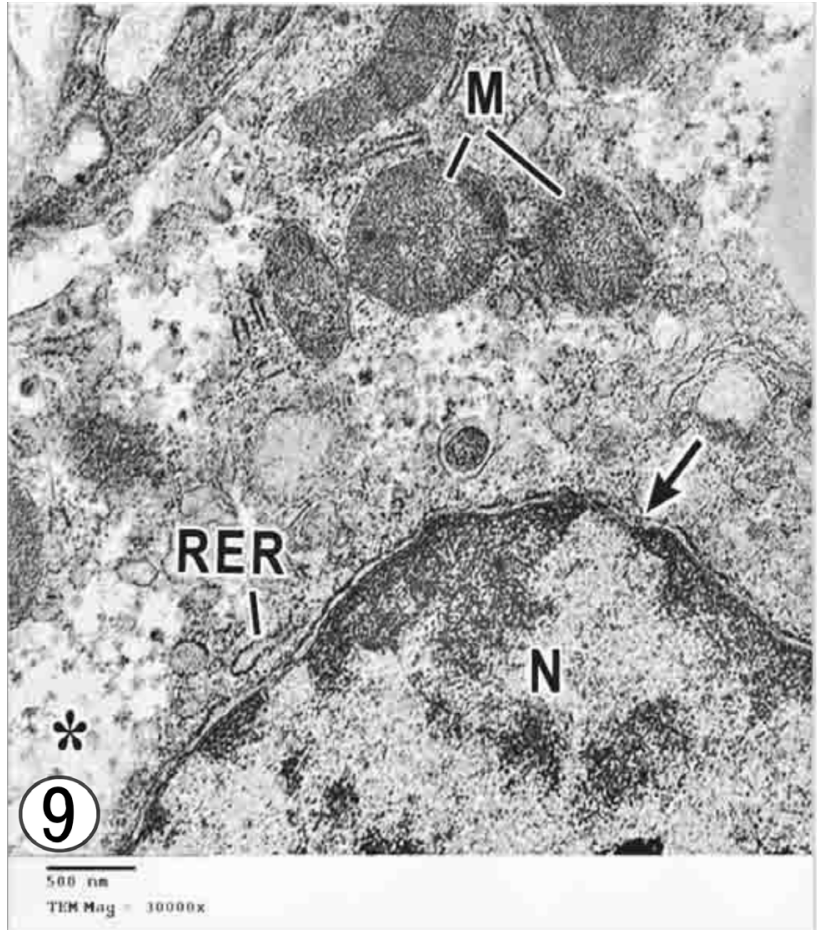

Fig. 9: Showing a portion of a hepatocyte demonstrating the cytoplasm of hepatocyte contains various shapes of mitochondria (M) reflecting features of pleomorphism phenomenon of the mitochondria, rough endoplasmic reticulum(RER)and glycogen rosettes $(*)$. Part of the nucleus $(\mathrm{N})$ with obvious nuclear envelope (arrow) is also observed.

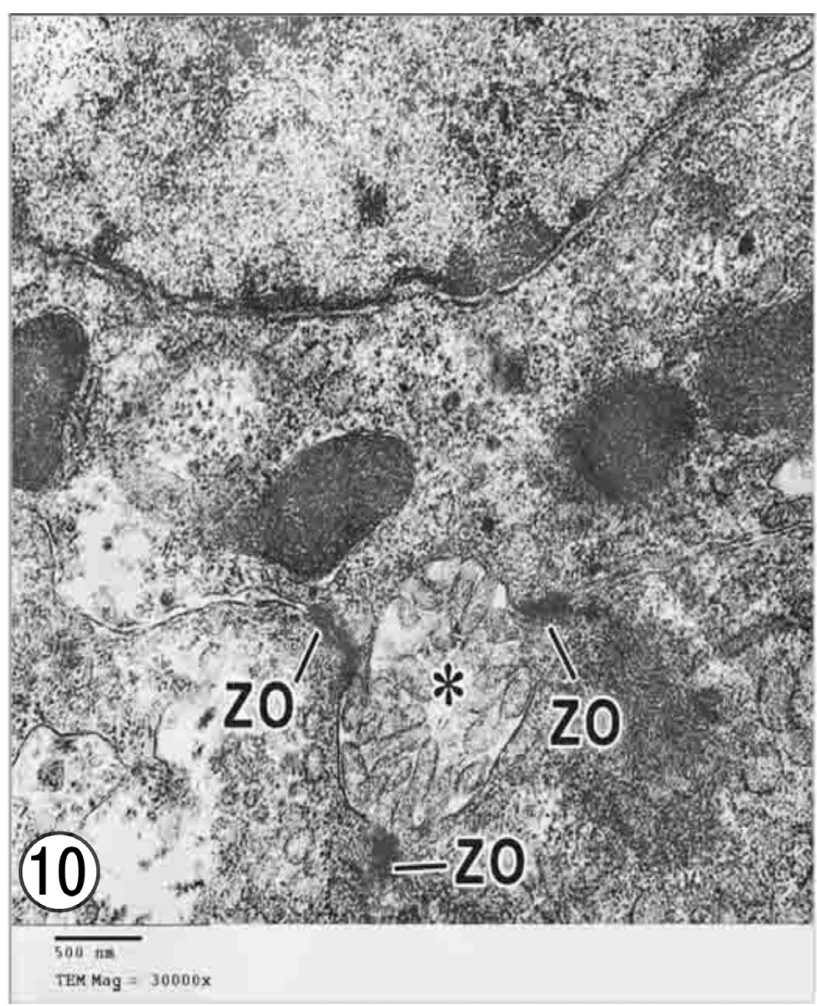

Fig. 10: Higher magnification electron micrograph illustrating a bile canaliculus $(*)$ bordered by three hepatocytes. Note the zonulaoccludens ( $\mathrm{ZO})$ at the convergence of the hepatic plasma membranes bordering the bile canaliculus. 


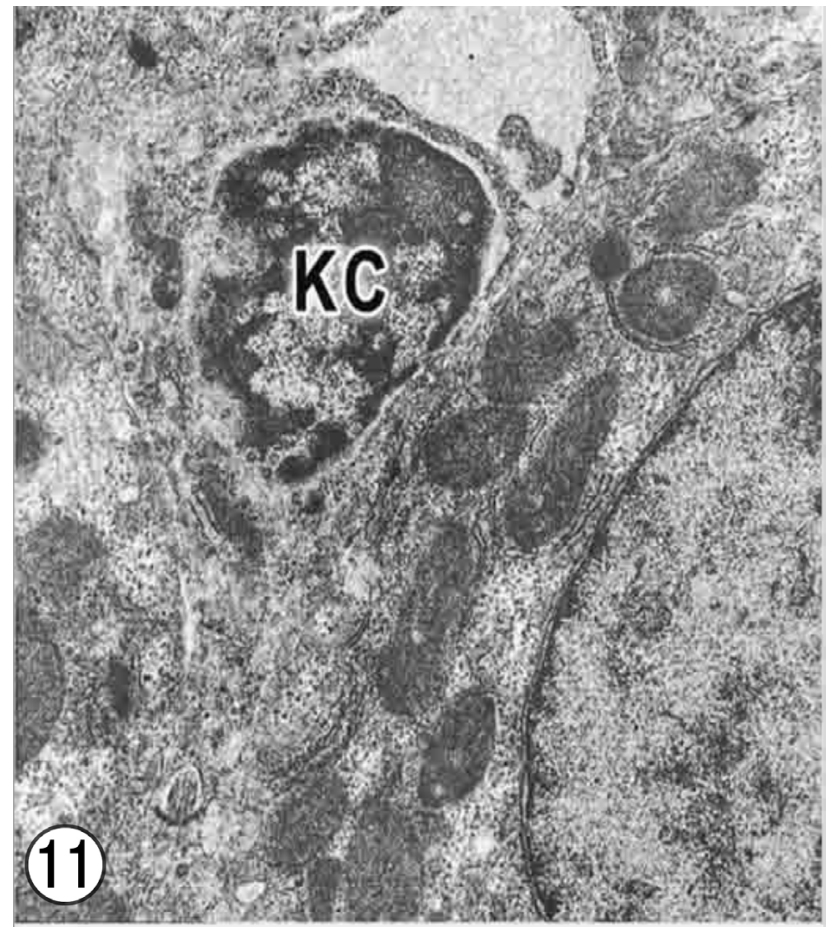

$\overline{500} \mathrm{~nm}$

Fig. 11: Showing hepatic sinusoid separated from adjacent hepatocyte by the space of Disse. The sinusoid is limited by aprominentKupffer cell(KC).

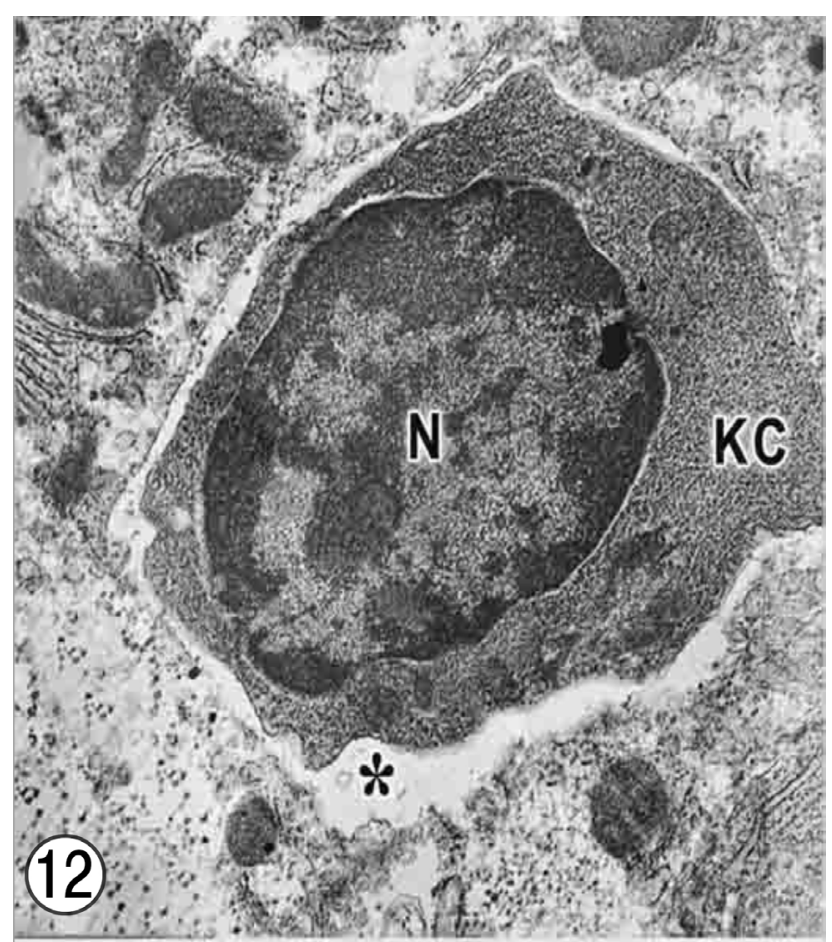

\section{$\overline{500 \mathrm{n}}$}

ТЕM MaO $-15000 x$

Fig. 12: Illustrating hepatic sinusoid separated from the hepatocyte by the space of Disse (*); Kupffer cell(KC)and its nucleus(N)localized in the lumen of the sinusoid.

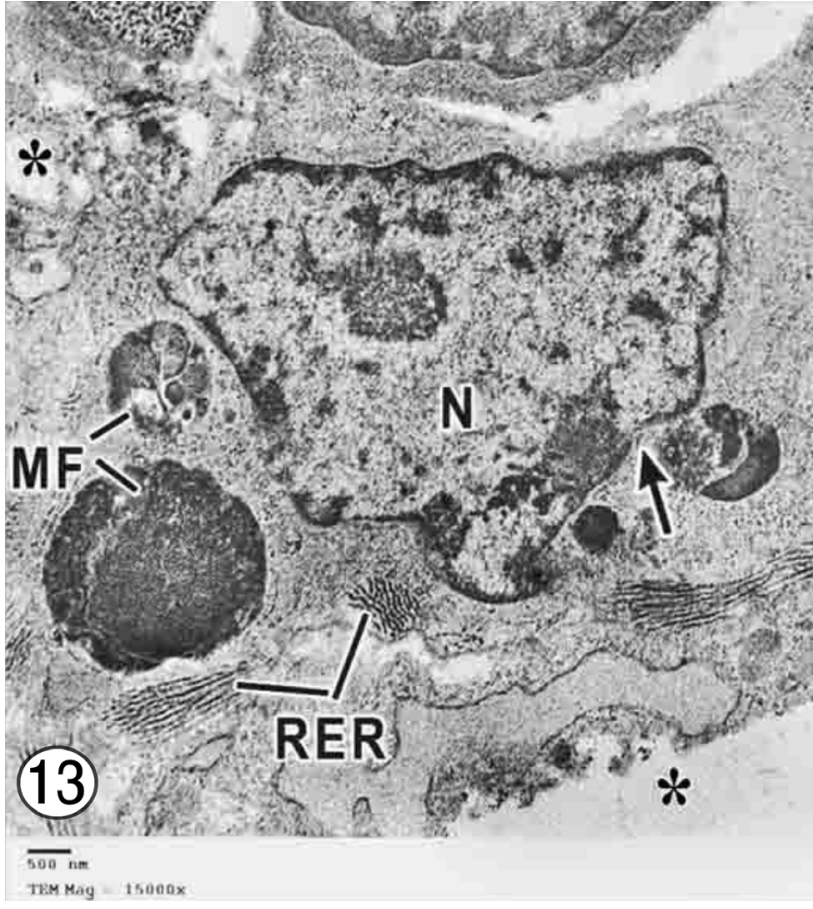

Fig. 13: Illustrating the hepatocyte with degenerated cytoplasm accompanied by the presence of vacuoles $(*)$, fragmented rough endoplasmic reticulum (RER) and myelin figure (MF). The nucleus $(\mathrm{N})$ shows irregular nuclear envelope(arrow).

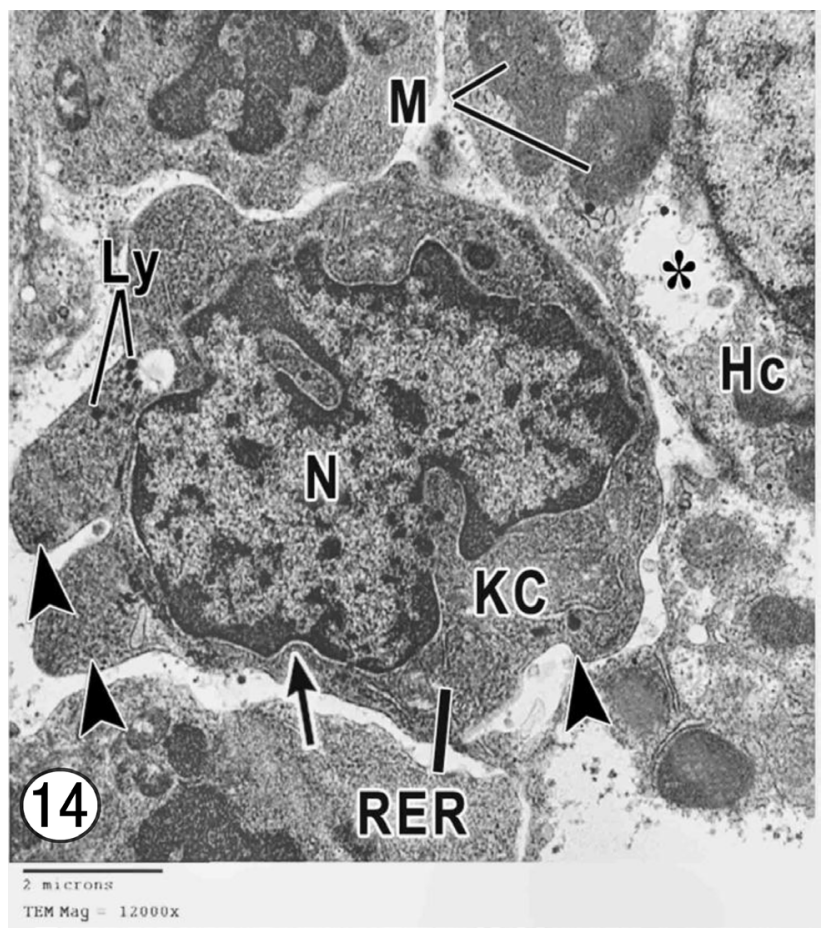

Fig. 14: Showing hypertrophied Kupffer cell(KC)possesses a large lobulated nucleus $(\mathrm{N})$ with irregular nuclear envelope(arrow). The cytoplasm contains lysosomes (Ly)and a few individual profiles of rough endoplasmic reticulum (RER). Notice, the extension of filopodia from the plasma membrane of Kupffer cell (arrowheads). The figure also shows part of a hepatocyte $(\mathrm{Hc})$ with disintegrated cytoplasm $(*)$ and disorganized mitochondria $(\mathrm{M})$. 


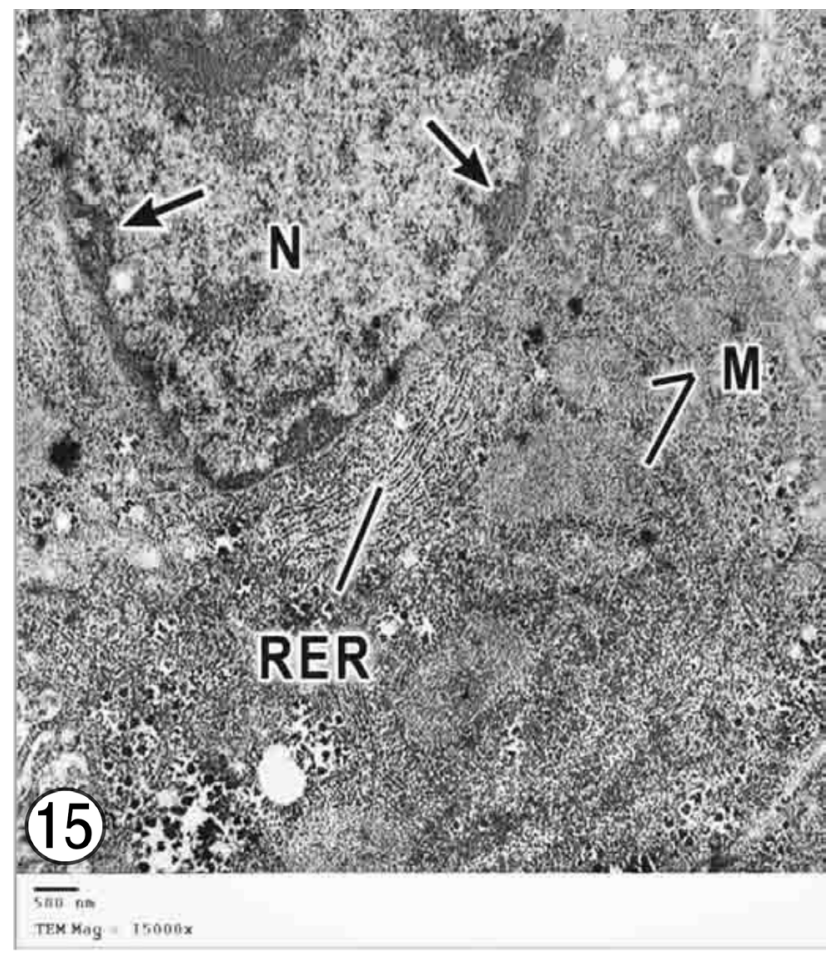

Fig. 15: Illustrating a hepatocyte with highly devastated mitochondria(M) which lost their internal ridges. The rough endoplasmic reticulum (RER)shows rather a fragmentation of their stacks into small rods, the nucleus $(\mathrm{N})$ manifests aggregation of heterochromatin (arrows) on the inner membrane of thenuclear envelope.

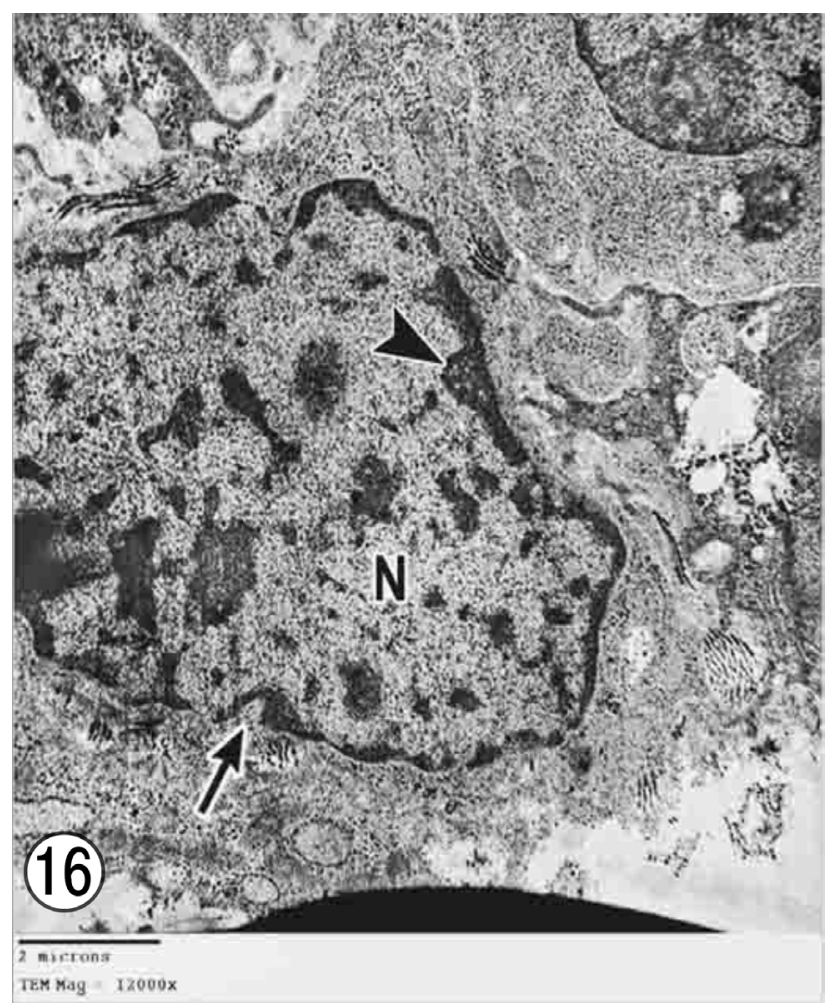

Fig. 16: Illustratinga hepatocyte with degenerated cytoplasm. Notice the nucleus $(\mathrm{N})$ with irregular nuclear envelope (arrow) and the heterochromatin (arrowhead) condensed on the inner membrane of this envelope.

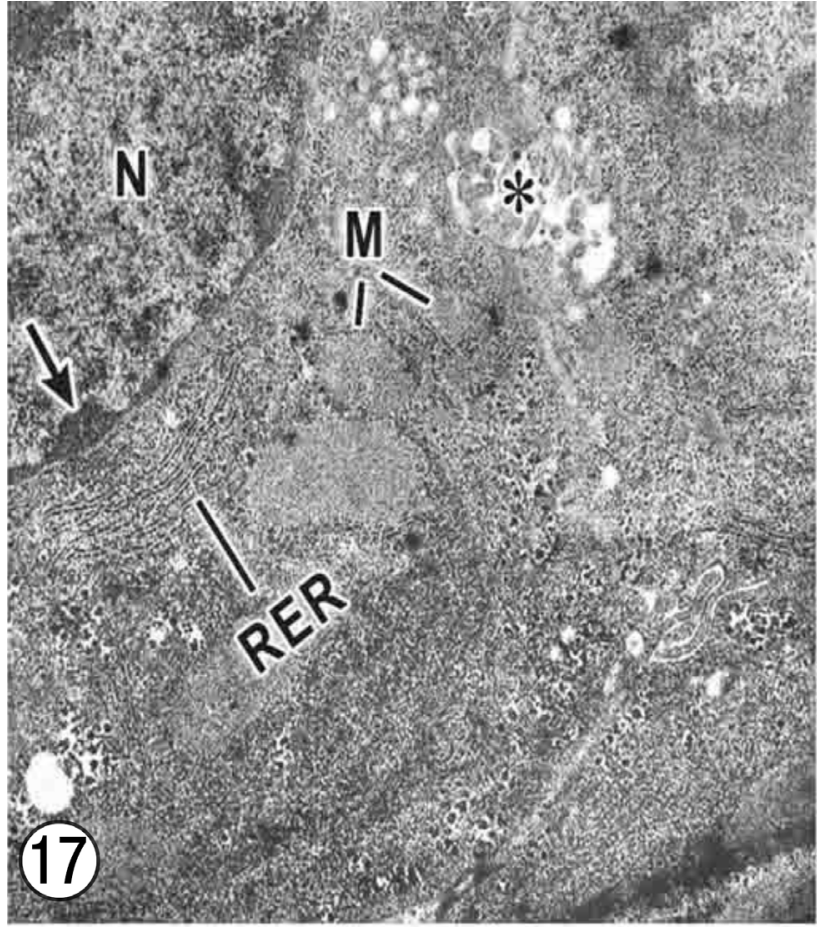

$\overline{5.00}$ tis

Fig. 17: Illustrating a hepatocyte with devastatedmitochondria(M) which lost their internal ridges. The rough endoplasmic reticulum (RER)shows rather a fragmentation of their stacks. The nucleus (N) shows aggregation ofheterochromatin (arrow). Bile canaliculus $\left(^{*}\right)$ isalso illustrated in the same figure.

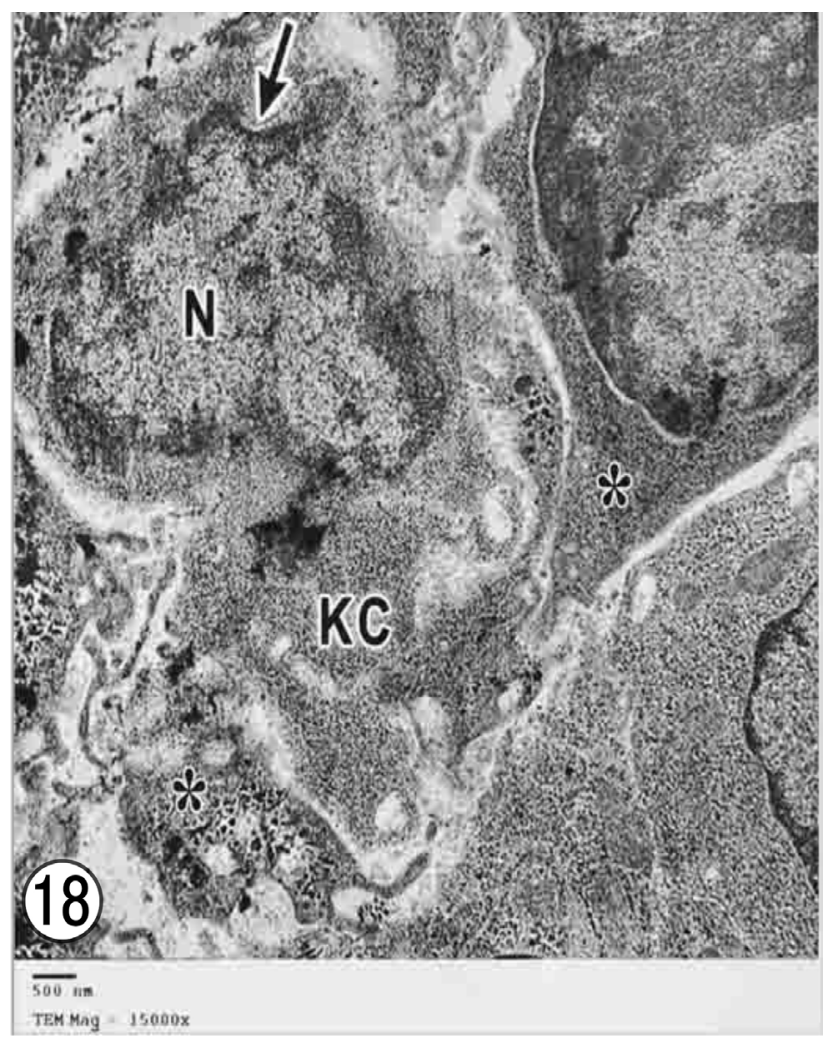

Fig. 18: Showing hepatic sinusoid $(*)$ contains Kupffer cell(KC) possesses degenerated cytoplasm and devastatednucleus(N) with disorganizednuclear envelope(arrow). 


\section{DISCUSSION}

Antibiotics remain important in pregnancy and may be second to only iron and food supplement ${ }^{[2]}$. The use of the antibiotics was extended in the medical area due to their great effect on the treatment of many cases of urinary tract infections ${ }^{[22]}$, acute otitis media ${ }^{[23]}$, and pneumonia ${ }^{[24]}$. In particular, the antibiotic resistance caused by $\beta$-lactamase production continues to present a growing challenge to the efficacy of $\beta$-lactams and their role as the most important class of clinically used antibiotics ${ }^{[25]}$. $\beta$-lactam drugs present high lipid solubility and low molecular weight, which permit the possibility to cross the placenta and reach the foetus ${ }^{[26]}$.

Amoxicillin is a broad-spectrum $\beta$-lactam antibiotic; due to its low toxicity, it is commonly used in obstetrics ${ }^{[27]}$.

In the present study, the beta-lactam antibiotic amoxicillin (E-mox) produced wide range of effects in maternally exposed mice foetuses. These alterations included histological and ultrastructural changes in the foetal liver of maternally treated mice.

Although the liver is particularly exposed to drugs and their metabolites, hepatic side-effects of antibiotics are far less frequent than other adverse effects such as gastrointestinal disorders. Antibiotic-related liver injuries cover most of the clinical and pathological aspects of hepatic dysfunction, including cytotoxic hepatitis (isoniazid), intrahepatic cholestasis (macrolides, penicillins, clavulanic acid), mixed hepatitis (sulphonamides), chronic active hepatitis (nitrofurantoin), or microvesicularsteatosis (tetracycline). In most cases, toxicity is idiosyncraticand unpredictable ${ }^{[28]}$.

The present investigation clearly illustrated that the application of 205 and $820 \mathrm{mg} / \mathrm{kg}$ body weight of amoxicillin to female mice during pregnancy had induced conspicuous consequences in the histological structure of the liver of foetuses of such treated animals. The major impairments comprised marked signs of damage of the hepatic cells which showed vacuolar degeneration; their nuclei exhibited obvious symptoms of pyknosis, karyorrhexis, and karyolysis in addition to the focal collection of inflammatory cells. The severity of such hepatic lesions was correlated with the drug dose. It was more obvious in foetuses of pregnant mice treated with the high dose of the antibiotic.

These results are in accordance with the findings of some authors who reported foetal liver damage in the form of vacuolization, cellular hypertrophy and necrosis in hepatocytes of rat foetuses of mothers exposed during pregnancy to the fluoroquinolone antibiotic ciprofloxacin ${ }^{[29]}$ or in rat offspring maternally treated with tetracycline ${ }^{[30]}$. Furthermore, supplementation with amoxicillin/clavulanic acid has been shown to cause histological alterations supported by a significant increase in liver function tests in treated rats ${ }^{[31]}$. Similar histopathological changes included degeneration of hepatocytes and increased number of megakaryocytes were reported in the liver of foetuses of maternally treated rats with the antibiotic dalacin- $\mathrm{C}^{[32]}$.

The present investigation showed erosion of their endothelial lining cells besides, activation of the phagocytic Kupffer cells. In confirmation of the present results, Mahmood ${ }^{[33]}$ reported hepatic tissue destruction along with hyperemia and congestion of centrilobularvein, lymphocytic infiltration around the portal space, as well as destruction and irregularity of hepatocytes in rats treated with gentamicin for 28 days $^{[33]}$. Additionally, similar degrees of deterioration of the hepatic sinusoids as well as marked activation of their defensive Küpffer cells, were reported, in the liver of mice exposed to lansoprazole ${ }^{[34]}$ From another angle, the marked degeneration and necrosis of the hepatocytes of maternally treated foetuses displayed in the present investigation may be correlated with the drug efficiency to induce inhibition of liver metabolism which consequently leads to hepatic injury and impairment of the liver function. The mechanisms underlying toxicity may be hypersensitivity-mediate; in some cases, the liver is not the primary target organ for toxicity but appears to mediate the clinical expression of some adverse effects induced by antibiotics $^{[28]}$.

It is worth mentioning that several investigations indicate that amoxicillin and Co-amoxiclav (Amoxicillin/ clavulanate) have a risk of hepatotoxicity in experimental animals ${ }^{[35-37]}$. In the same line, numerous case reports have been published regarding the higher incidence of liver injury in patients treated with a combination of amoxicillin and clavulanic acid compared with those supplied with amoxicillin alone. Such cases of liver injury in patients exposed to amoxicillin-clavulanic acid were offered by several investigators ${ }^{[38-41]}$. The authors elucidated that the histopathological impacts included degeneration of hepatocytes and lymphocytic infiltration in patients treated with the antibiotic Co-amoxiclav (Amoxicillin/ clavulanate).

The present investigation illustrated ultrastructural changes of the hepatocytes of foetuses of maternally treated mice with 205 and $820 \mathrm{mg} / \mathrm{kg}$ body weight of amoxicillin. These changes were more severe in the liver of mice fetuses maternally treated with the high dose of the antibiotic during organogenesis. These effects were represented by alterations in the cytoplasm and nuclei of the affected hepatocytes. The most affected organelles included the mitochondria and rough endoplasmic reticulum. The mitochondria exhibited swelling with obvious condensation of their indistinguishable matrices that displayed high electron density. The rough endoplasmic reticulum showed fragmentation of their cisternae into smaller stacks accompanied with loss of their attached ribosomes. The nuclei of the hepatocytes showed an irregular nuclear envelope. Myelin figures enclosing dense bodies were also observed in the cytoplasm. The hepatic sinusoids exhibited hypertrophied Kupffer cell with an irregular surface accompanied by an extension of filopodia. The cytoplasm of Kupffer cells contained lysosomes, a few 
individual profiles of rough endoplasmic reticulum and a large lobulated nucleus with marginated large masses of heterochromatin and irregular nuclear envelope.

Similar observations were postulated that tetracycline supplementation to rats caused alterations in hepatocytes, represented by swollen mitochondria with fragmented cristae and reduced profiles of the rough endoplasmic reticulum $^{[42}$ and ${ }^{43}$. In addition, presence of morphological changes of the hepatocytes mitochondria and their matrix in the liver of guinea pig foetuses maternally treated with the antibiotic chlortetracycline ${ }^{[4]}$. Also, female Wistar rats received $400 \mathrm{mg} / \mathrm{kg}$ of the antibiotic rifampicin showed morphological changes in the endoplasmic reticulum, Golgi apparatus, and mitochondria of the hepatocytes ${ }^{[45]}$. Furthermore, some investigators observed cytoplasmic vacuoles and ballooned mitochondria in the liver of rat foetuses maternally treated with acetylsalicylic acid ${ }^{[46]}$. vacuolization, cellular hypertrophy, and necrosis in hepatocytes of rat offspring maternally treated with tetracycline ${ }^{[30]}$. Similar features of mitochondrial injuries obtained in rat hepatocytes under the effect of adriamycin ${ }^{[4]}$. Comparable electron microscopic findings were noticedinthe liver ofguinea pigs injected with cisplatin for 7 days followed by the antibiotic gentamicin for 9 days $^{[48]}$.

An explanation of the marked alterations of the liver of maternally treated foetuses could be attributed to the cytotoxicity of the drug doses through inhibiting mitochondrial oxidative phosphorylation ${ }^{[49]}$. In this respect ${ }^{[50]}$, reported that antibiotics inhibit mitochondrial oxidation of fatty acids in mice; both free fatty acids and their microsomal $\beta$-oxidation end-products (the dicarboxylic fatty acids) are toxic to the mitochondria. This toxicity perhaps contributes to the severity of the liver disturbances produced by high doses of antibiotics. Severe inhibition of $\beta$-oxidation can lead to microvesicularsteatosis ${ }^{[51]}$.

\section{CONCLUSION}

The obtained results referred clearly to that the betalactam antibiotic amoxicillin caused various histological and ultrastructural alterations at the level of the liver in mice foetuses subjected intraperitoneally to this antibiotic for 8 days during gestation.

\section{CONFLICTS OF INTEREST}

There are no conflicts of interest.

\section{REFERENCES}

1. Mitchell AA, Gilboa SM, and Werler MM, et al.: Medication use during pregnancy, with particular focus on prescription drugs. Am. J. Obstet. Gynecol., (2011) 205: 51- 58.

2. Norwitz ER, and Greenberg JA : Antibiotics in Pregnancy: Are they safe? Rev. Obstet. Gynecol., (2009) 2(3): 135 -136.
3. Rather IA, Kim B, and Bajpai V: Self-medication and antibiotic resistance: Crisis, current challenges, and prevention. Saudi J. Biol. Sci., (2017)24: 808-812.

4. Li B, and Webster TJ: Bacteria antibiotic resistance: New challenges and opportunities for implant-associated orthopaedic infections. J. Orthop. Res., (2018) 36(1): 22-32.

5. Brogden RN, Heel RC, and Speight TM et al:: Amoxicillin injectable: A review of its antibacterial spectrum, pharmacokinetics and therapeutic use. Drugs, (1979) 18(3): 169-184.

6. Reagan-Shaw S, Nihal M, Ahmad N: Dose translation from animal to human studies revisited. FASEB J., (2008) 22 (3): 659-661.

7. Shin JW, Seol IC, and Son CG: Interpretation of animal dose and human equivalent dose for drug development. J. Korean Orient. Med., (2010)

31: 351-357.

8. Kaur SP, Rao R, and Nanda SA: Amoxicillin: A broad spectrum antibiotic. Int. J. Pharm. Pharm. Sci., (2011) 3(3): 30-37

9. Galloway JH: Antibiotic toxicity in white mice. Lab. Anim. Care, (1968)18: 421-425.

10. Baldwin JA, Schardien JL, and Koshima Y: Reproduction studies of BRL14151K and BRL25000: II. Peri- and postnatal studies in rats. Chemotherapy (Tokyo), (1983) 31: 252-262.

11. Abou-Tarboush FM : Teratogenic and toxic effects of Hiconcil (amoxicillin) on mouse fetuses. Arab Gulf J.Sci.Res., (1994)12: 133-140.

12. Morris TH: Antibiotic therapeutics in laboratory animals. Lab. Anim., (1995)29(1): 16-36.

13. Parvova I, Danchev N, and Hirstov E: Animal models of human diseases and their significance for clinical studies of new drugs. J. Clin. Med., (2011) 4(1): 19-29.

14. Gottberg B, Berné J, and Quiñónez B, et al.: Prenatal effects by exposing to amoxicillin on dental enamel in Wistar rats. Med.Oral Patol. Oral Cir. Bucal., (2014)19(1): e38-43.

15. Belkacem N, Hong E, and Antunes A, et al.: Use of animal models to support revising meningococcal breakpoints of $\beta$-lactams. Antimicrob. Agents Chemother., (2016) 60(7): 4023-4027.

16. Chesa-Jiménez J, Peris JE, and Torres-Molina F, et al.: Low bioavailability of amoxicillin in rats as a consequence of presystemic degradation in the intestine. Antimicrob. Agents Chemother., (1994) 38: 842-847.

17. JECFA[Joint FAO/WHO Expert Committee on Food Additives] Toxicological Evaluation of Certain Veterinary Drug Residues in Food. WHO Food Additives Series 66. World Health Organisation Press, Geneva, Switzerland(2012): 
18. Snell GD: Biology of The Laboratory Mouse. $5^{\text {th }}$ ed., the Blakiston Company, Philadelphia (1956).

19. Reynolds ES: The use of lead citrate at high $\mathrm{pH}$ as an electron opaque stain in electron microscopy. J. Cell Biol., (1963)17: 208-212.

20. Dykstra MJ, Mann PC, and Elwell MR, et al.: Suggested standard operating procedures (SOPs) for the preparation of electron microscopy samples for toxicology/pathology studies in a GLP environment. Toxicol. Pathol., (2002)30: 735-743.

21. De Tejada BM: Antibiotic use and misuse during pregnancy and delivery: Benefits and risks. Int. J. Environ. Res. Public Health , (2014) 11(8): 7993-8009.

22. Jancel T, and Dudas V: Management of uncomplicated urinary tract infections. West. J. Med., (2002) 176(1): 51-55.

23. Piglansky L, Leibovitz E, and Raiz S, et al. : Bacteriologic and clinical efficacy of high dose amoxicillin for therapy of acute otitis media in children. Pediatr. Infect. Dis. J., (2003) 22(5): 405-412.

24. Abgueguen P, Azoulay-Dupuis E, and Noel $\mathrm{V}$, et al:: Amoxicillin is effective against penicillin-resistant Streptococcus pneumoniae strains in a mouse pneumonia model simulating human pharmacokinetics. Antimicrob. Agents Chemother., (2007)51(1): 208-214.

25. Tehrani $\mathrm{KH}$, and Martin NI , $\beta$-lactam $/ \beta$ lactamase inhibitor combinations: an update. Med. Chem. Commun., (2018) 9(9): 1439-1456.

26. Nahum GG, Uh $1 K$, and Kennedy DL: Antibiotic use in pregnancy and lactation: what is and is not known about teratogenic and toxic risks. Obstet. Gynecol., (2006) 107(5): 1120-1138.

27. Zaręba-Szczudlik J, Romejko-Wolniewicz E, and Lewandowski Z, et al.: Evaluation of the amoxicillin concentrations in amniotic fluid, placenta, umbilical cord blood and maternal serum two hours after oral administration. Neuro Endocrinol. Lett., (2017) 38(7): 502-508.

28. Westphal JF, Vetter D, and Brogard JM: Hepatic side-effects of antibiotics. J. Antimicrob. Chemother., (1994) 33(3): 387-401.

29. Channa MA, and Janjua, MZ: Effects of ciprofloxacin on foetal hepatocytes. J. Pak. Med. Assoc., (2003) 53 (10): 448-450.

30. Machado AL, Brandão AA, and Silva CM, et al:: Influence of tetracycline in the hepatic and renal development of rat's offspring. Braz. Arch. Biol. Technol., (2003) 46(1): 47-52.
31. Olayinka ET, and Olukowade IL: Effect of amoxycillin/clavulanic acid (Augmentin 625) on antioxidant indices and markers of renal and hepatic damage in rats. J. Toxicol. Environ. Health Sci., (2010) 2(6): 85-92.

32. El-Ghareeb AE, Amer MA, and Abdelrahman HA, et al:: Biological and histopathological studies on the effect of the antibiotic Clindamycin on albino rat fetuses. Asian J. Anim. Sci., (2016) 4(4):795 - 802.

33. Mahmood NA, Haleh MO, Mohammad PO, et al:: Pathological changes of gentamicin in liver tissue and antioxidant property of cinnamon extract on Wistar rats. Biomed. Pharm. J., (2014) 7: 341-347.

34. Ramadan RA, Yousef $\mathrm{OMH}$, and El-Wessamy AMM: The pathogenic effects of the anti-ulcer drug lansoprazole (Zollipak) on the liver of albino mice. J. Egypt. Ger. Soc. Zool., (2005) 46 (C): 41-56.

35. Zaidi SA: Hepatitis associated with amoxicillin/ clavulanic acid and/or ciprofloxacin. (2003) Am. J. Med. Sci., 325(1): 31-33.

36. Andrade RJ, Lucena MI , and Fernández MC, et al.: Drug-induced liver injury: An analysis of 461 incidences submitted to the Spanish registry over a 10-year period. Gastroenterology, (2005) 129(2): 512-521.

37. El-Sherbiny AE, Taye A, and Abdel-Raheem I: Role of ursodeoxycholic acid in prevention of hepatotoxicity caused by amoxicillin-clavulanic acid in rats. Annal. Hepatol., (2009) 8(2): 134-140.

38. Larrey D, Vial T, and Micaleff A et al.: Hepatitis associated with amoxycillin-clavulanic acid combination, report of 15 cases. Gut, (1992) 33(3): 368-371.

39. Hautekeete ML, Bernard R, and Horsmans $\mathrm{Y}$ et al.: Liver injury related to amoxicillin-clavulanic acid: Interlobular bile- duct lesions and extrahepatic manifestations. J. Hepatol., (1995)22(1): 71-77.

40. Limauro DL, Chan-Tompkins NH, and Carter RW et al.: Amoxicillin/clavulanate-associated hepatic failure with progression to Stevens-Jhonson syndrome. Ann. Pharmacother., (1999) 33(5): 560-564.

41. Rodriguez GLA, Stricker BH, and Zimmerman $\mathrm{HJ}$ : Risk of acute liver injury associated with the combination of amoxicillin and clavulanic acid. Arch. Intern. Med., (1996)156 (12): 1327-1332.

42. Gray JE, Weaver RN, and Skinner P et al.: Effects of tetracycline on ultrastructure and lipoprotein secretion in the rat hepatocyte. Toxicol. Appl. Pharmacol., (1974) 30(2), 317-332.

43. Fromenty B, and Pessayre M: Impaired mitochondrial function in microvesicular steatosis: Effects of drugs, ethanol, hormones and cytokines. J.Hepatol., (1997) 26: 43-53. 
44. Rdmert, PAUL and Matthiessen ME: Tetracyclineinduced changes in hepatocytes of mini-pigs and mini-pig foetuses as revealed by electron microscopy. Acta Pathol. Microbiol. Scand. (1986) [A], 94(1-6): 125-131.

45. Piriou A, Maissiat $\mathrm{R}$, and Jacqueson A et al:: Ultrastructural changes in the parenchymal liver cells of rats treated with high doses of rifampicin. Br. J. Exp. Pathol., (1987) 68(2): 201-207.

46. Espiridiao SR, Oliveira-Filho $M$, and Kulay L: Liver and kidney ultrastrucural changes caused by acetylsalicylic acid treatment during pregnancy in rats. Clin. Exp. Obstet. Gynecol., (2002) 29: 37-39.

47. Pedrycz A, and Brzeski Z: L-arginine decreases heat shock protein 70 (marker of environmental stress) expression in kidney cells of rat fetuses during apoptosis-late effect of adriamycin action. Ann. Agric. Environ, Med., (2006) 13(1): 129-132.
48. Kohn S, Fradis M, Robinson E, et al.: Hepatotoxicity of combined treatment with cisplatin and gentamicin in the guinea pig. Ultrastruct. Pathol., (2005) 29(2): 129-137.

49. Rush GF, Alberts D, Lupo $\mathrm{S}$ et al:: Toxicity of H2-receptor antagonists to isolated rat hepatocytes: Structure activity relationships. J. Pharmacol. Exp. Ther., (1988) 244 (1): 113-117.

50. Fréneaux E, Labbe G, Letteron $\mathrm{P}$, et al.: Inhibition of the mitochondrial oxidation of fatty acids by tetracycline in mice and in man: Possible role in microvesicular steatosis induced by this antibiotic Hepatology, (1988) 8(5): 1056-1062.

51. Labbe G, Pessayre D, and Fromenty B: Drug induced liver injury through mitochondrial dysfunction: Mechanisms and detection during preclinical safety studies. Fundam.Clin. Pharmacol., (2008) 22(4): 335-353. 
الملخص العربى

\title{
دراسات نسيجية وتركيبية دقيقة على تاثير عقار الاموكسيسيلين

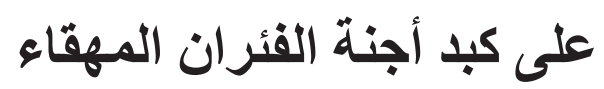

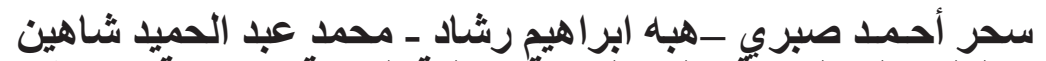

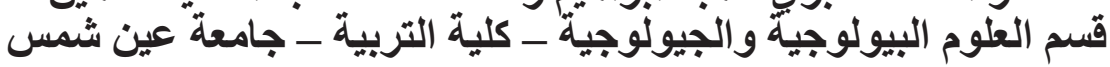

مقدمة: على الرغم من الدور الفعال الذى تلعبه المضادات الحيوية البيتالاكتامية فى علاج الألتهابات التى تسببها البكتيريا مثل التهابات الأذنهوالأنف والحنجرة و عدوي الأجهزه التنفسية والبولية.و تعتبر المضادات الحيوية من المركبات الهامه اثناء فترة الحمل وربما احتلت المرتبة الثانية بعد المكملات الغذائية والعناصر المعدنية وبالرغم من هذه الإستخدامات المفيدة لهذه العقاقير ، إلا هناك بعض التقارير الطبية التي تتسب إليها فى إحداث بعض الآثار الجانبية

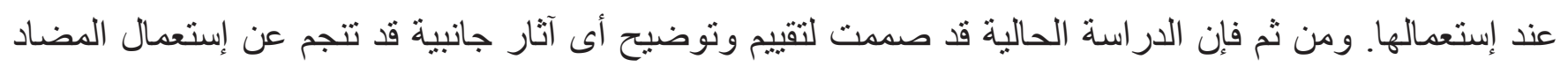
الحيوي أموكسيسيلين ( 205 و 820 مليجر ام لكل كيلو جر ام من وزن الجسم ) على كبد أجنة الأمهات المعالجة بالمضاد الحيوي ومقارنتها بأجنة المجمو عة الضابطة، وذلك من النواحى الهستولوجية والتركيبية الدقيقة. المواد والطرق: ولتحقيق هذه الأهداف فقد صممت الدر اسة كالآتى: أجريت التجربة على مجموعة من إناث الفئر ان المهقاء الحو امل و أجنتها حيث قسمت إلى ثنلاث مجمو عات. و أعتبرت المجمو عة الأولى هي المجموعة الضابطة - وقد حقنت إناث هذه المجمو عة داخل التجويف البريتونى بالمذيب (المحلول الملحى الفسيولوجى) وذللك لمدة ثمانية أيام منتالية (من اليوم السابع إلى اليوم الرابع عشر من الحمل). أما الأمهات الحو امل للمجموعتين الثانية والثالثة فقد حقتت بالمضاد الحيوي أموكسيسيلين بجرعتين (205 و 820مليجرام لكل كيلو جر ام من وزن الجسم ، على الترتيب) لمدة ثمانية أيام متتالية (من اليوم السابع إلى اليوم الر ابع عشر من الحمل) وبالطريقة نفسها داخل التجويف البرتنيونى.

النتائج: أظهرت الفحوص النسيجية للكبد فى أجنة الاناث المعالجة بالمضاد الحيوي حدوث تهدم و اضح فى الخلايا الكبدية علي شكل تحلل فجوي للسيتوبلازم. وكذلك حالات مختلفة من البكنزة و التحلل النووى. فضلا عن حدوث إحتقان و إتساع للوريد المركزي و الجيوب الدموية المحيطة به وفقدان للخلايا المبطنة لهم وازدياد نشاط خلايا كبفر البلعمية. كما أظهرت الفحوص التركيبية الدقيقة بالمجهر الالكتروني النافذ للخلايا الكبدية حدوث تغيير ات في بعض عضيات الخلايا تمثلت في الميتوكوندرياو الثبكة الأندوبلازمية الخشنة. حيث أظهرت المينوكوندرياإنتفاخ و تجمع للحشوه التي

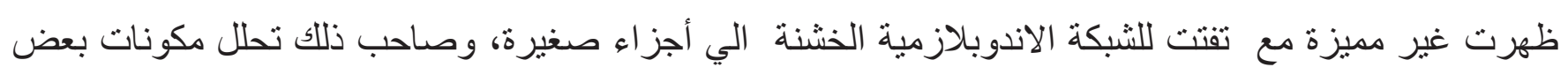
الأنوية و عدم انتظام أغلفتها النووية. الخلاصة: تخلص نتائج الدراسة الحالية إلى أن المضاد الحيوي أموكسيسيلين له آثار سلبية على أجنة الفئر ان الحوامل التى تم معاملة أمهاتها لمدة ثمانية أيام خلال الحمل، و التى أنعكست على التركيب النسيجى لكبد أجنة الفئران البيضاء فى الظروف التجريبية التى تمت فيها الدر اسة. 